\title{
Evaluation of Marker Enzymes in Fibroid Patients
}

\author{
O. C. Ojo and A. O. Oyeyemi \\ Department of Biochemistry, Ekiti State University,Ado-Ekiti.
}

\begin{abstract}
Marker enzymes such as acid phosphatase(ACP), alkaline phosphatase(ALP) and aspartate transaminase(AST) levels were estimated in the serum of 60 fibroid patients and 60 non-fibroid patients from UTH, Ado-Ekiti. The age, weight and height of the patients were also considered. Results obtained showed a significant increase in the level of $A C P\left(12.15 \pm 6.02^{a} \mu / L\right)$, significant decrease in $A S T\left(10.24 \pm 3.10^{a} \mu / L\right)$ level, and no significant difference was recorded in ALP $\left(14.99 \pm 2.20^{a} \mu / L\right)$ level when compared to the control $\left(10.10 \pm 6.15^{a} \mu / L\right),\left(12.40 \pm 3.11^{a} \mu / L\right)$ and $\left(15.52 \pm 1.30^{a} \mu / L\right)$ respectively. Significant increase in both the age and weight of fibroid patients were also observed which could be related to the etiology of fibroid while height (not significant) may not be related to fibroid. However, this study showed that the activity of ALP does not change in fibroid cases while there are changes in the activities of both ACP and AST.
\end{abstract}

\section{Introduction}

The uterus or womb is a major female hormone responsive reproductive sex organ of most mammals including human in which foetus is developed (Blackburn and Flemming, 2011). One of the major and pathological disorder affecting the uterus is a disease called uterine myomas, fibromyomas and leiomyomas (Okolo, 2008), which develops during the early and later reproductive years of women. About 20 to $80 \%$ of women within the age of 30 to 50years and approximately three out of four women usually develop one or more fibroid in her life time (Garg et al., 2011).

Fibroid is a benign or non canceroustumor that grows from the smooth muscle layer (myometrium) of the uterus which can range from small size as that of a pea to bigger size as that of a melon. The disease is common in women who weigh over $70 \mathrm{~kg}$. This is taught to be due to higher level of oestrogen hormone that occurs in larger women (Neiger et al., 2006). When it is often multiple and if the uterus contains too many leiomyomata to count, it is then referred to as diffuse uterine leiomyomatosis.

The exact etiology of the disease is not clearly understood but working hypothesis has it that genetic predisposition, prenatal hormone exposure and the effect of hormones, growth factor and xenoestrogen causes fibroid growth (Garg et al., 2011). Known risk factors are African-American women as likely as Caucasian women, nulliparity, obesity, polycystic ovary syndrome, diabetes and hypertension (Okolo, 2008).

While a bimanual examination typically can identify the presence of larger fibroids gynaecologic ultrasonography (ultrasound) has evolve as the standard tool to evaluate the uterus for fibroids. Sonography will depict the fibroids asmasses with a heterogenous texture, which usually cause shadowing of the ultrasound beam. The location can be determined and dimensions of the lesion measured. Also, magnetic resonance imaging (MRI) can be used to define the depiction of the size and location of the fibroids within the uterus (Goto et al., 2002).

Enzymes on the other hand are biological catalysts which speed up the rate at which chemical reactions take place, particularly within the cells of organisms. This process involves the binding of the substrate and breaking or making of chemical bonds. The outcome is a specific change to the substrate which creates a new chemical molecule or product.

Enzymes such as alkaline Phosphatase (ALP), acid Phosphatase (ACP) and Aspartate transaminase (AST) can be used as tumor marker (Eissa, 1999). Tumor markers are produced in small concentration by normal cells but increase in concentration when produced by tumor cells.

However, the levels and the association of these marker enzymes (ACP, ALT and AST) with the development of fibroids in the uterus were therefore evaluated in this study.

\section{Methodology}

$5 \mathrm{mls}$ of venous blood collected into an heparin bottle and centrifuged. The plasma was collected and placed in another bottle containing no anticoagulant for analysis.

Aspartate transaminase activity was determined by the method described (Tietz, 1986). Alkaline phosphatase and acid phosphatase was assayed using the method described by (Tiez and Rinker, 1986). 
III. Result

Table 1: Parameters of blood plasma showing the mean acid Phosphatase, Aspartate transaminase and alkaline Phosphatase values in fibroid patients.

\begin{tabular}{|c|c|c|c|c|}
\hline \multirow{2}{*}{\multicolumn{2}{|c|}{ DATA OF STUDY }} & \multicolumn{2}{|c|}{ NON-FIBROID PATIENTS } & FIBROID PATIENTS \\
\hline & & RANGE & $\mathrm{MEAN} \pm \mathrm{SD}$ & RANGEMEAN \pm SD \\
\hline Ages (yrs) & & $25-35$ & $28.0 \pm 4.2^{\mathrm{a}} 30-46$ & $41.0 \pm 3.2^{b}$ \\
\hline Weight $(\mathrm{kg})$ & $46-65$ & $52.5 \pm 12.02^{\mathrm{a}}$ & 59.91 & $74.5 \pm 2.10^{\mathrm{b}}$ \\
\hline Height (Ft) & & $4.0-6.1$ & $5.2 \pm 4.02^{\mathrm{a}}$ & $3.91-6.15 .3 \pm 4.0^{\mathrm{a}}$ \\
\hline \multicolumn{3}{|c|}{ Alkaline Phosphatase $(\mu / \mathrm{L})$} & $10.10 \pm 6.40^{\mathrm{a}}$ & $12.15 \pm 6.02^{\mathrm{a}}$ \\
\hline \multicolumn{3}{|c|}{ Aspartate transaminase $(\mu / \mathrm{L})$} & $12.4 \pm 3.11^{\mathrm{a}}$ & $10.24 \pm 3.10^{\mathrm{a}}$ \\
\hline \multicolumn{3}{|c|}{ Alkaline Phosphatase $(\mu / \mathrm{L})$} & $15.25 \pm 1.30^{\mathrm{a}}$ & $16.79 \pm 2.10^{\mathrm{a}}$ \\
\hline
\end{tabular}

Values are given as mean \pm S.D

Values not showing a common superscript letter differ significantly as $\mathrm{P}<0.005$. Hence, superscript $\mathrm{a}$ and $\mathrm{b}$ indicate significant difference $\mathrm{P}<0.05$.

\section{Discussion}

Fibroids are the most common benign tumors in females and typically found during the middle and later reproductive years. However, result earlier published suggested that in addition to the parent molecule of the oxidative metabolites of oestrogen, including the CEs 2-hydroxyl $\mathrm{E}_{2}$, 4-hydroxylE $\mathrm{E}_{2}$ and 16-hydroxyl $\mathrm{E}_{2}$ may also affect oestrogen induced human uterine leiomyoma growth (Al-Hendy and Salome, 2006). Recent report from the same lab demonstrated that the development of uterine leiomyoma is associated with high COMT expression, and that specific COMT genotypes are associated with higher enzyme activity (Salama et al., 2006). Therefore, interrupting oestrogen metabolism or the oestrogen receptor (ER) signalling pathway may be a viable strategy for many therapeutic modalities.

The table above shows the mean value of the age, weight, height, ACP, AST, ALP of both fibroid and non fibroid patients. The weight of the fibroid patient $\left(74.5 \pm 2.10^{b} \mathrm{~kg}\right)$ was higher than that of non-fibroid patients $\left(52.5 \pm 12.02^{\mathrm{a}} \mathrm{kg}\right)$. Also, the age of fibroid patients $\left(41.0 \pm 3.2^{\mathrm{a}} \mathrm{kg}\right)$ was higher than that of non-fibroid patients $\left(28.0 \pm 4.2^{\mathrm{a}} \mathrm{kg}\right)$. The T-test shows a significant difference in their mean values. This result is in agreement with Okolo 2008 that the risk of fibroid increases with age, and weight increases by $21 \%$ with each $10 \mathrm{~kg}$ increase in fibroid mass which indicates that age and weight may be related to fibroid.

Result of the activity of ALP shows a reduction in the activity of ALP in fibroid patients $(14.99 \pm 2.2 \mu / \mathrm{L})$ to that of non-fibroid patients $(15.25 \pm 1.30 \mu / \mathrm{L})$ indicating no significant difference in their mean values. The decrease in the activity of alkaline phosphate activity may not be related to fibroid. This result agreed with the previous work of Lange et al (1992) that activity of serum ALP in fibroid patients shows an overlap with the control and therefore not predictive of fibroid.

Result of the activity of Acid phosphatase shows a significant increase in the activity in the enzyme in fibroid patients $(12.15 \pm 6.02 \mu / \mathrm{L})$ compare to that of non-fibroid patients $(10.10 \pm 6.15 \mu / \mathrm{L})$. The increase observed in the ACP level could be attributed to the presence of fibroid in the uterus of the patient, this in agreement with that of Allen (1995).

\section{Conclusion}

This study revealed that the Serum activity of acid phosphatase increases in fibroid patient and could therefore be used as a marker both for diagnosis and to monitor treatment.

\section{References}

[1]. Al-Hendy A, Lee E.J, Wang H.Q, Copland J.A (2006): Gene therapy of uterineleiomyomas :Adenovirus-mediated expression of dominant negative oestrogen receptor inhibits tumor growth in nude mice. Am J .Obstet Gynecol.191:1621-1631

[2]. Allen, S.M. (1995). "An enzyme linked immunosorbent assay (ELISA) for detection of swmenal fluid using a monoclonal antibody to prostatic acid phosphatase" JImmunoassay 16:297-308

[3]. Blackburn, D., Flemming, A. (2011). Invasive implantation and intimate placental association in a placentotrophic African lizard. Journal of Morphorlogy1 $1: 45-46$.

[4]. Eissa, S. (1999).Tumor makers.Lippincott and Wilkins. Philadelphia. 745-746.

[5]. Garg,K., Tickoo, S.,Soslow, R.A., Reuter, V.E. (2011). "Morphologic features of uterine leiomyomas Associated with hereditary leiomyomatosis and renal cell carcinoma syndrome" The American Journal of Surgical Pathology (8) : 1235-1237.

[6]. Goto, A., Takeuchi, S., Sugimura, K., Maruo, T. (2002). "Usefulness of Gd-DTPA contrast enhanced dynamic MRT and serum determination of LDH and its isoenzymes in the differential diagnosis of leiomyosarcoma from degenerated leiomyoma of the uterus."Int. J. Gynecol. Cancer. 12 (4): 354-3 61.

[7]. Lange P.H, Millan J.L, Stigbrand T, Vessella R.L, FishmanW.H(1992).Placental alkaline phosphatase as tumor marker for seminoma. Cancer Res. 42(8):3244-3247.

[8]. Neiger R, Sonek J, Croom C, Ventolini G (2006). Pregnancy related changes in the size of uterineleiomyomas. The Journal of Reproductive Medicine 51 (9):671-674. 
[9]. Okolo, S. (2008). "Incidence, aetiology and epidemiology of uterine fibroids." Best Practice \& Research Clinical Obstetrics \&Gynecology 22(4) : 571-588.

[10]. Salama, S. A., Ho, S., Wang, H., Tenhumen, J., Tilgmann C., Al-Hendy A.(2006).

[11]. Hormonal regulation of catechol-o-methyl transferase activity in women with uterine leiomyomas. Fertilsteril. $86: 259-262$.

[12]. Tietz, N. W.(1986). Determination of aspartase transaminase and alanine transaminase activity in serum. Inn; Textbook of clinical chemistry.W B. Saunders and company. $3^{\text {rd }}$ edition. 674-677.

[13]. Tietz, N.W., and Rinker, A. O., (1986). The measurement of alkaline phosphatase.ln : Analytical concept in Enzymology. H.A. Homburger, Ed. Skokie, College of America Pathologist 195-203. 